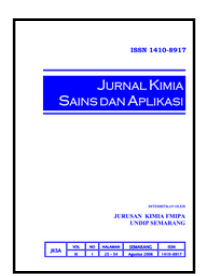

\title{
Studi Filogeni dan Uji Potensi Bioremediasi serta Enzim Termostabil Ekstraseluler Isolat Geobacillus sp. dari Sumber Air Panas Gedong Songo
}

\author{
Maulida Indriyaning Ratri ${ }^{a}$, Purbowatiningrum Ria Sarjono ${ }^{a^{*}}$, Agustina L.N. Aminin ${ }^{a}$ \\ a Biochemistry Laboratory, Chemistry Department, Faculty of Sciences and Mathematics, Diponegoro University, Jalan Prof. \\ Soedarto, Tembalang, Semarang 50275 \\ * Corresponding author: purbowatining@live.undip.ac.id
}

\begin{tabular}{|c|c|}
\hline Article Info & Abstract \\
\hline $\begin{array}{l}\text { Keywords: } \\
\text { Thermophilic } \\
\text { microorganisms, } \\
\text { Geobacillus sp, } \\
\text { bioremediation }\end{array}$ & $\begin{array}{l}\text { Thermophilic microorganisms are microorganisms that are resistant to high } \\
\text { temperatures with optimum growth temperature reaching more than } 60^{\circ} \mathrm{C} \text {. } \\
\text { Thermophilic microorganisms have many uses such as, for bioremediation and } \\
\text { thermostable enzyme producer. This study aims were to explore the potential of } \\
\text { Geobacillus sp. from the Gedong Songo hot spring through the construction of phylogeny } \\
\text { trees and to obtain potential bioremediation data of Fe (III), Pb (II), H2O2 and } \\
\text { extracellular enzymes from Geobacillus sp. The construction of phylogeny trees was } \\
\text { performed using Phylip } 3.68 \text { ed program with parsimony method. Test the potential of } \\
\text { Geobacillus sp. for bioremediation of Fe (III) and Pb (II) was performed by inoculating the } \\
\text { pellet Geobacillus sp. on BSM (Basal Saline Medium) containing Fe (III) and Pb (II) } \\
\text { respectively. Analysis of Fe (III) and Pb (II) on the medium was performed by AAS. Test } \\
\text { of H2O2bioremediation potential was conducted qualitatively by observing the presence } \\
\text { of O2 bubbles produced by catalase activity from Geobacillus sp. Amylase enzyme activity } \\
\text { test, } \beta \text {-galactosidase and extracellular protease were done qualitatively with addition of } \\
\text { each starch, ONPG and gelatin as its substrate respectively. The study showed positive } \\
\text { results on the bioremediation potential of Fe (III) and Pb (II) as well as for the test of } \\
\text { enzyme amylase and extracellular protease. Test of bioremediation potential of H2O2 } \\
\text { and extracellular } \beta \text {-galactosidase enzyme showed negative result. The construction of } \\
\text { phylogeny trees shows that the eight isolates of Geobacillus sp. has the closest genetic } \\
\text { relation to Geobacillus sp. TERI NSM and Geobacillus sp. Sbs3. }\end{array}$ \\
\hline
\end{tabular}

\section{Abstrak}

Kata kunci: Mikroorganisme termofilik, Geobacillus sp, bioremediasi
Mikroorganisme termofilik merupakan mikroorganisme yang tahan terhadap suhu tinggi dengan suhu optimum pertumbuhan mencapai lebih dari $60^{\circ} \mathrm{C}$. Mikroorganisme termofilik mempunyai banyak kegunaan, antara lain untuk proses bioremediasi dan penghasil enzim termostabil. Penelitian ini bertujuan untuk menelusuri potensi Geobacillus sp. dari sumber air panas Gedong Songo melalui konstruksi pohon filogeni serta mendapatkan data potensi bioremediasi $\mathrm{Fe}(\mathrm{III}), \mathrm{Pb}(\mathrm{II}), \mathrm{H}_{2} \mathrm{O}_{2}$ dan enzim ekstraselular dari isolat Geobacillus sp. Konstruksi pohon filogeni dilakukan menggunakan program Phylip 3.68 ed dengan metode parsimony. Uji potensi Geobacillus sp. untuk bioremediasi $\mathrm{Fe}(\mathrm{III})$ dan $\mathrm{Pb}$ (II) dilakukan dengan menginokulasikan pellet Geobacillus sp. pada media BSM (Basal Salin Medium) yang mengandung masing-masing $\mathrm{Fe}(\mathrm{III})$ dan $\mathrm{Pb}$ (II). Analisis kadar $\mathrm{Fe}(\mathrm{III})$ dan $\mathrm{Pb}(\mathrm{II})$ pada media dilakukan dengan AAS. Uji potensi bioremediasi $\mathrm{H}_{2} \mathrm{O}_{2}$ dilakukan secara kualitatif dengan melihat adanya gelembung $\mathrm{O}_{2}$ yang dihasilkan oleh aktifitas katalase dari Geobacillus sp. Uji aktivitas enzim amilase, $\beta$-galaktosidase dan protease ekstraseluler dilakukan secara kualitatif 
dengan penambahan masing-masing amilum, ONPG dan gelatin sebagai substratnya. Penelitian menunjukkan hasil positif pada uji potensi bioremediasi $\mathrm{Fe}$ (III) dan $\mathrm{Pb}$ (II) serta untuk uji enzim amilase dan protease ekstraseluler. Uji potensi bioremediasi $\mathrm{H}_{2} \mathrm{O}_{2}$ dan enzim $\beta$-galaktosidase ektraseluler menunjukkan hasil negatif. Konstruksi pohon filogeni menunjukkan bahwa kedelapan isolat Geobacillus sp. memiliki kekerabatan terdekat dengan Geobacillus sp._TERI_NSM dan Geobacillus sp. sbs3.

\section{Pendahuluan}

Mikroorganisme termofilik merupakan mikroorganisme yang tahan terhadap suhu tinggi dengan suhu optimum pertumbuhan mencapai lebih dari $60^{\circ} \mathrm{C}$ [1]. Mikroorganisme termofilik dapat diisolasi dari sumber air panas seperti Thermococcus kodakaraensis dengan suhu optimum pertumbuhan $85^{\circ} \mathrm{C}$ [2] dan Geobacillus thermoleovorans dari sumber air panas Gedong Songo dengan suhu pertumbuhan $74^{\circ} \mathrm{C}$ [3].

Mikroorganisme termofilik mempunyai banyak potensi, antara lain untuk proses bioremediasi. Bioremediasi adalah proses pengolahan limbah dengan memanfaatkan kemampuan terakumulasi dan terkonsentrasinya zat polusi atau logam dari suatu cairan/limbah oleh material biologi, selanjutnya melalui proses pengolahan lebih lanjut, cairan/limbah ini dapat dibuang dan ramah terhadap lingkungan [3]. Kondisi limbah yang mengandung logam berat sering kali masih dalam keadaan panas dalam proses pengolahannya. Oleh karena itu dibutuhkan mikroorganisme pengikat logam yang tahan pada suhu tinggi atau mikroorganisme termofilik. Contohnya adalah bakteri Geobacillus thermoleovorans dari sumber air panas Gedong Songo yang mampu mengikat besi (III), sulfat dan nitrat dengan temperatur optimum $65^{\circ} \mathrm{C}[4]$.

Selain untuk proses bioremediasi material, mikroorganisme termofilik sangat bermanfaat karena dapat menghasilkan protein-protein enzim termostabil [5]. Misalnya Pyrococcus furiosus yang dapat menghasilkan enzim hidrolase dan glikosintase pada suhu $80^{\circ} \mathrm{C}$ [6], alfa amylase dari Bacillus licheniformis yang dapat menghidrolisis pati, protease dari Bacillus stearothermophilus [7] dan laktase dari Streptococcus thremophilus yang dimanfaatkan dalam industri yogurt [8].

Berdasarkan penelitian yang telah dilakukan oleh [9] pada sumber air panas Gedong Songo telah diisolasi delapan isolat Geobacillus, yaitu Geobacillus sp. dYTae-1, Geobacillus sp. dYTae-3, Geobacillus sp. dYTae-5, Geobacillus sp. dYTae-13, Geobacillus sp. dYTae-14, Geobacillus sp. dNBae-1, Geobacillus sp. dNBae-3X, Geobacillus sp. dGae-3. Kedelapan isolat tersebut telah ditentukan urutan nukleotidanya dari gen 16S rRNA, namun belum diketahui potensinya.

Salah satu cara untuk menelusuri potensi mikroorganisme adalah dengan menggunakan pohon filogeni. Pada penelitian ini dilakukan konstruksi pohon filogeni terhadap kedelapan isolat Geobacillus sp. untuk mengetahui tingkat kekerabatan dari isolat-isolat Geobasillus sp. tersebut dengan bakteri-bakteri lain.
Bakteri yang mempunyai hubungan filogenetik yang dekat, diperkirakan sifat-sifat dari mikroorganisme tersebut relatif sama, sehingga kemungkinan memiliki potensi biomolekuler yang sama pula. Berdasarkan informasi potensi bakteri yang memiliki kekerabatan terdekat dengan kedelapan isolat Geobacillus sp., maka potensi biomolekuler dari kedelapan Geobacillus sp., dapat diperkirakan.

Delapan isolat Geobacillus sp. tersebut berasal dari sumber air panas Gedong Songo. Widarto dan Yudistira [10] dalam penelitiannya membuktikan bahwa kadar Fe pada sumber air panas Gedong Songo (GS 2) pada tahun 2003 mencapai 92,15 ppm, sehingga diperkirakan isolat Geobacillus sp. dapat menggunakan Fe(III) dalam pertumbuhannya sehingga berpotensi untuk digunakan dalam bioremediasi Fe(III). Penelitian [11]Hussein dkk, 2004 Pseudomonas sp. menghasilkan bahwa bakteri tersebut dapat mengakumulasi beberapa logam berbeda sehingga terdapat kemungkinan kedelapan isolat Geobacillus sp. juga mempunyai potensi bioremediasi untuk logam selain Fe.

\section{Metode Penelitian}

Alat

Alat-alat yang digunakan adalah sentrifugator (Beckman model J2-21), inkubator (Memmert model 300), pH meter, kulkas (Sanyo dan Polytron), botol semprot, alat-alat kultur sel, Atomic Absorption Spectroscopy (Shimadzu), autoklaf (Clinical Autoclave Prestige Medical series 2100), gelas beker, tabung reaksi, labu ukur, botol vial, corong kaca, mikropipet, pipet tetes, kertas saring dan pengaduk.

\section{Bahan}

Bahan yang digunakan dalam penelitian ini adalah isolat bakteri termofilik Geobacillus sp., media Basal Saline Medium (BSM), Yeast Tripton(YT), Nutrient Broth (NB), larutan $\mathrm{FeCl}_{3}, \mathrm{PbSO}_{4}, \mathrm{H}_{2} \mathrm{O}_{2}, \mathrm{H}_{2} \mathrm{SO}_{4}$, Spirtus, Alkohol $70 \%$, ONPG (o-nitrovenil- $\beta-D-G a l a k t o s i d a s e)$, gelatin, laktosa, pati kanji (amilum), bakto agar dan akuades.

\section{Cara Kerja}

\section{Konstruksi Pohon Filogeni}

Konstruksi pohon filogeni terhadap isolat Geobacillus sp. dilakukan dengan program Phylip (Phylogeny Inference Package) 3.68 ed. Pada paket program Phylip, dipilih program seqboot, DNApars dan consense. 


\section{Peremajaan Bakteri}

Media Basal Saline Medium (BSM) tersusun dari $\mathrm{K}_{2} \mathrm{HPO}_{4} ; \mathrm{KH}_{2} \mathrm{PO}_{4} ;\left(\mathrm{NH}_{4}\right)_{2} \mathrm{SO}_{4} ; \mathrm{MgSO}_{4} \cdot 7 \mathrm{H}_{2} \mathrm{O} ; \mathrm{FeCl}_{3} .6 \mathrm{H}_{2} \mathrm{O}$; $\mathrm{NaCl}$; dan $\mathrm{CaCl}_{2} \cdot 2 \mathrm{H}_{2} \mathrm{O}$ yang dilarutkan dalam akuades. Media BSM tersebut dibuat dengan $\mathrm{pH}$ 6. Sebanyak 100mL media BSM yang ditambah nutrisi disterilisasi. Media cair ini digunakan untuk peremajaan isolat bakteri. Isolat Bakteri murni diambil dengan menggunakan mikropipet, kemudian diinokulasikan ke dalam media BSM dan diinkubasi pada suhu $55^{\circ} \mathrm{C}$ selama 24 jam.

\section{Uji Potensi Bioremediasi logam Fe (III)}

Masing-masing isolat Geobacillus sp. yang telah diremajakan diambil dengan menggunakan mikro pipet, dan diinokulasikan ke dalam media BSM yang baru dan diinkubasi pada suhu $55^{\circ} \mathrm{C}$. Media BSM yang telah ditumbuhi isolat Geobacillus sp. disentrifuge pada 4000 rpm selama 10 menit untuk mengendapkan bakteri. Pellet bakteri Geobacillus sp. yang didapatkan diinokulasikan pada media BSM yang mengandung Fe(III) 34,5 ppm kemudian diinkubasi pada suhu $55^{\circ} \mathrm{C}$. Media yang telah ditumbuhi Geobacillus sp. disentrifuge pada $4000 \mathrm{rpm}$ selama 10 menit hingga didapatkan filtrat dan diuji kadar Fe(III) yang masih tersisa dengan AAS.

\section{Uji Potensi Bioremediasi logam Pb (II)}

Masing-masing isolat Geobacillus sp. yang telah diremajakan diambil dengan menggunakan mikropipet kemudian diinokulasikan kedalam media BSM yang baru dan diinkubasi pada suhu $55^{\circ} \mathrm{C}$. Media BSM yang telah ditumbuhi isolat Geobacillus sp. disentrifuge pada 4000 rpm selama 10 menit untuk mengendapkan bakteri. Pellet bakteri Geobacillus sp. yang didapatkan diinokulasikan pada media BSM yang mengandung 7,5 $\mathrm{mg} / \mathrm{L}$ larutan $\mathrm{Pb}$ (II) dan diinkubasi pada suhu $55^{\circ} \mathrm{C}$. Kemudian disentrifuge pada 4000 rpm selama 10 menit. Supernatant yang didapatkan dianalisis dengan AAS (Atomic Absorption Spectroscopy) untuk mengetahui kadar $\mathrm{Pb}$ yang masih tersisa pada larutan.

Uji Potensi Bioremediasi $\mathrm{H}_{2} \mathrm{O}_{2}$

Masing-masing isolat Geobacillus sp. yang telah diremajakan diambil dengan menggunakan mikro pipet kemudian diinokulasikan ke dalam media BSM untuk mendapatkan stater. Media tersebut diinkubasi pada $55^{\circ} \mathrm{C}$ hingga keruh yang menandakan bakteri telah tumbuh. Media yang telah ditumbuhi bakteri diteteskan pada kaca preparat kemudian ditetesi $\mathrm{H}_{2} \mathrm{O}_{2}$ aktivitas katalase pada mikroba dapat diketahui dengan terbentuknya gelembung-gelembung gas $\mathrm{O}_{2}$.

\section{Uji Amilase Ekstraseluler}

Uji amilase ekstraseluler dilakukan dengan membuat media BSM padat yang mengandung pati kanji. Sebanyak $30 \mathrm{~mL}$ media dituang ke dalam cawan Petri dan didiamkan hingga memadat. Kemudian isolat bakteri diteteskan pada media, lalu diinkubasi pada suhu $30^{\circ} \mathrm{C}$. Setelah 48 jam, cawan digenangi dengan larutan lugol (1 g kristal iodin, $2 \mathrm{~g}$ KI, $300 \mathrm{ml}$ akuades) dan didiamkan sekitar 1 menit agar iodin bereaksi. Adanya daerah tak berwarna di sekitar koloni menunjukkan aktivitas enzim amilase.

\section{Uji $\beta$-Galaktosidase Ekstraseluler}

Masing-masing isolat Geobacillus sp. diambil dengan menggunakan mikro pipet kemudian diinokulasikan ke dalam media cair BSM yang mengandung $1 \%$ laktosa dan diinkubasi pada suhu $55^{\circ} \mathrm{C}$ selama 24 jam. Kemudian inokulum ditambah dengan larutan ONPG (o-nitrovenil- $\beta$-D-Galaktosidase) dan diinkubasi selama 3-5 jam. Adanya $\beta$-Galaktosidase ekstraseluler ditandai dengan perubahan warna dari kuning pucat menjadi berwarna jingga/kuning tua.

\section{Uji Protease Ekstraseluler}

Uji protease ekstraseluler dilakukan dengan menghidrolisis gelatin. Bakteri yang diuji diinokulasikan ke dalam media BSM yang ditambah dengan gelatin kemudian diinkubasi pada $55^{\circ} \mathrm{C}$ selama 24 jam hingga media sedikit keruh yang menandakan telah ditumbuhi bakteri. Setelah itu media disimpan di dalam lemari es selama 15 menit. Apabila media tetap cair menunjukkan adanya hidrolisis gelatin oleh protease yang dihasilkan bakteri sedangkan bila media memadat maka tidak terjadi hidrolisis gelatin oleh protease yang dihasilkan bakteri.

\section{Hasil dan Pembahasan}

\section{Studi Filogeni}

Studi filogeni dilakukan untuk mengetahui tingkat kekerabatan dari kedelapan isolat Geobacillus sp. khas Gedong Songo. Analisis filogenetik ini didasarkan pada sekuen parsial gen 16S rRNA yang merupakan penanda molekuler dengan fungsi yang identik pada seluruh organisme. Molekul 16S rRNA memiliki beberapa daerah yang memiliki urutan basa yang relatif konservatif dan beberapa daerah urutan basanya variatif [12].

Berdasarkan hasil analisis Blast $\mathrm{N}$ dari data Gene Bank dengan urutan DNA gen 16S rRNA, terdapat 100 spesies bakteri yang memiliki kemiripan 97-99\% dengan kedelapan isolat Geobacillus sp. Penjajaran urutan nukleotida gen $16 \mathrm{~S}$ rRNA dari kedelapan isolat Geobacillus sp. dilakukan dengan program Clustal W dan dihasilkan data pada gambar 1 :
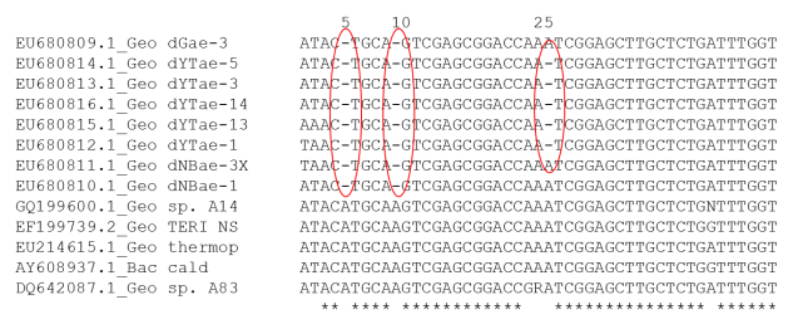

Gambar 1. urutan nukleotida gen 16S rRNA dari kedelapan isolat Geobacillus sp.

Berdasarkan data tersebut diketahui bahwa pada penjajaran urutan nukleotida gen 16S rRNA dari kedelapan Geobacillus sp. terdapat delesi yang tidak ditemukan pada urutan nukleotida gen 16S rRNA dari spesies bakteri yang lain. Delesi terjadi pada basa kelima 
dan kesepuluh dari data penjajaran gen 16S rRNA. Delesi spesifik tersebut menunjukkan bahwa kedelapan Geobacillus sp. mempunyai perbedaan dengan spesies bakteri lain yang menunjukkan bahwa bakteri Gedong Songo adalah khas.

Konstruksi pohon filogeni dilakukan menggunakan program Phylip (Phylogeny Inference Package) 3,68 ed dengan metode parsimony, dan dihasilkan pohon filogeni yang menunjukkan kekerabatan dari kedelapan isolat Geobacillus sp. dengan 92 spesies bakteri lainnya.

Berdasarkan pohon filogeni dari 100 spesies bakteri tersebut, dipilih 17 spesies bakteri yang memiliki tingkat kekerabatan terdekat dengan Geobacillus sp. Gedong Songo untuk dibandingkan lebih lanjut dengan kedelapan isolat Geobacillus sp., sehingga dihasilkan pohon filogeni yang lebih spesifik dari 25 spesies bakteri yang disajikan pada gambar 2 .

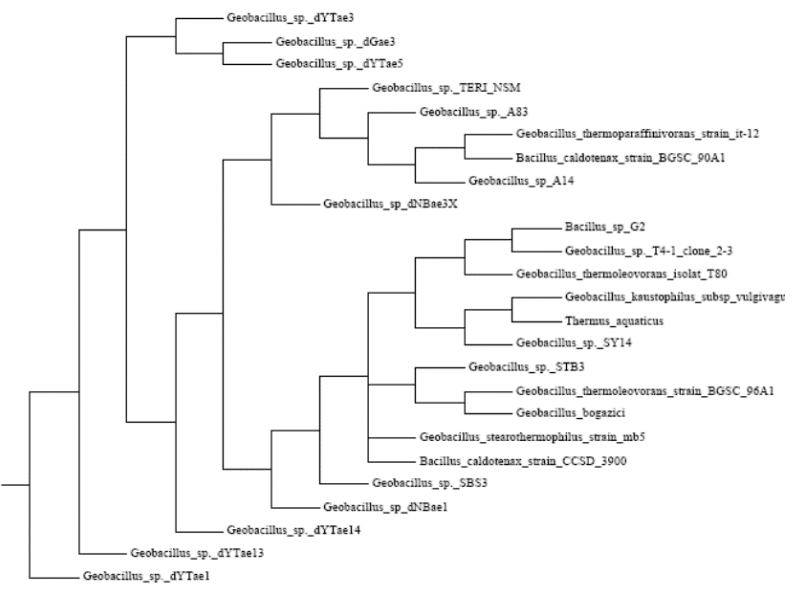

Gambar 2. Pohon filogeni dari 25 spesies bakteri

Berdasarkan pohon filogeni tersebut, dapat diketahui bahwa kedelapan isolat Geobacillus sp. Gedong Songo berada dalam satu kelompok kekerabatan yang dekat. Kedekatan kekerabatan tersebut menunjukkan kemiripan sifat pada kedelapan isolat Geobacillus sp., dibuktikan dengan adanya kemiripan data potensi bioremediasi dan enzim ektraseluler dari kedelapan isolat Geobacillus sp. yang telah didapatkan pada penelitian ini.

Spesies lain yang memiliki tingkat kekerabatan yang dekat dengan dengan kedelapan isolat Geobacillus sp. adalah Geobacillus_sp._TERI_NSM yang ditemukan oleh Nitu Sood dan Banwari Lal (NCBI. Accession Number EF199739, 2009) serta Geobacillus sp. sbs3 yang ditemukan oleh Tayyab,M., Rasool,N., Jalal,A. dan Rashid,N (NCBI. Accession Number AB306518, 2009). Berdasarkan potensi spesies bakteri yang mempunyai kekerabatan yang dekat dengan Geobacillus sp. Gedong Songo, maka potensi dari Geobacillus sp. dapat ditelusuri. Bakteri yang mempunyai hubungan filogenetik yang dekat, diperkirakan sifat-sifat dari mikroorganisme tersebut relatif sama, sehingga kemungkinan memiliki potensi yang sama pula. Selain itu dapat pula diketahui mikroorganisme alternatif untuk masing-masing isolat dalam pemanfaatannya.
Potensi molekuler sebagian besar spesies bakteri yang memiliki kekerabatan terdekat dengan kedelapan isolat Geobacillus sp. belum dieksplorasi lebih lanjut. Pada penelitian ini akan dieksplorasi lebih lanjut potensi molekuler kedelapan isolat Geobacillus sp. sebagai agen bioremediasi $\mathrm{Fe}(\mathrm{III}), \mathrm{Pb}$ (II) dan $\mathrm{H}_{2} \mathrm{O}_{2}$ serta potensi enzim ekstraseluler terhadap amilase, $\beta$-Galaktosidase dan protease.

\section{Uji Potensi Bioremediasi Fe (III)}

Delapan isolat Geobacillus sp. tersebut berasal dari sumber air panas Gedong Songo yang mengandung Fe(III). Widarto dan Yudistira [10] dalam penelitiannya membuktikan bahwa kadar Fe pada sumber air panas Gedong Songo (GS 2) pada tahun 2003 mencapai 92,15 ppm. Dari hasil tersebut diperkirakan isolat Geobacillus $s p$. dapat menggunakan Fe(III) dalam pertumbuhannya sehingga berpotensi untuk digunakan dalam bioremediasi $\mathrm{Fe}(\mathrm{III})$.

Pellet bakteri Geobacillus sp. diinokulasikan pada media BSM yang mengandung $\mathrm{Fe}(\mathrm{III}) 34,5 \mathrm{ppm}$. Pengamatan dilakukan setiap hari untuk mengetahui pertumbuhan bakteri yang diindikasikan dengan kekeruhan media. Pada hari ketiga, media sudah terlihat keruh. Hal ini menunjukkan bahwa Geobacillus sp. mampu tumbuh pada media BSM dengan Fe(III) 34,5 ppm.

Kultur Geobacillus sp. yang berusia 4 hari disentrifuge pada $4000 \mathrm{rpm}$ selama 10 menit untuk mengendapkan bakteri hingga didapatkan filtrat yang bebas bakteri yang selanjutnya akan diuji kadar Fe(III) yang masih tersisa dengan AAS dengan panjang gelombang 248,3 nm. Berdasarkan data yang dihasilkan pada gambar 3, diketahui bahwa kadar $\mathrm{Fe}(\mathrm{III})$ pada media telah berkurang untuk masing-masing isolat Geobacillus sp. Hal ini menunjukkan bahwa kedelapan isolat Geobacillus sp. mampu mengabsorpsi Fe(III).

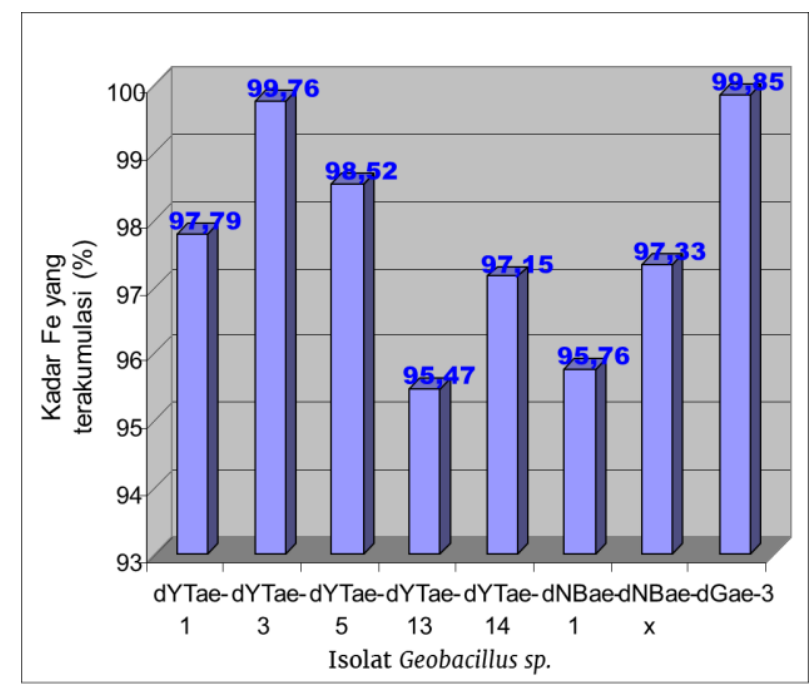

Gambar 3. Pengujian kadar Fe(III) oleh isolat Geobacillus sp

Secara umum proses bioremediasi logam berat oleh mikroorganisme melalui dua mekanisme yaitu ekstraseluler dan intraseluler yang terjadi secara 
bersamaan . Proses ekstraseluler biasa disebut biosorbsi. Proses ini terjadi ketika ion logam berat terikat pada dinding sel dengan dua cara. Pertama melalui pertukaran ion di mana ion-ion bermuatan positif pada dinding sel digantikan oleh ion-ion logam berat. Kedua adalah formasi kompleks antara ion-ion logam berat dengan biopolimer seperti polisakarida dan protein yang berada pada dinding sel mikroorganisme yang berperan penting dalam mengikat ion logam. Geobacillus $s p$. merupakan bakteri gram positif, dimana dinding selnya terdiri dari peptidoglikan [9]. Peptidoglikan adalah polimer dari 3 macam building block, yaitu N-acetyl Glucosamine (NAG), N-Acetyl Muramic Acid (NAM), Peptida yang dibangun oleh 4 asam amino (tetrapeptida) yang terdiri dari beberapa $\mathrm{D}$-asam amino. Ketiga senyawa tersebut sangat efektif sebagai zat penjerap logam [13]. Gugus fungsi seperti karbonil, amino, thiol, hidroksi, fosfat, dan hidroksi-karboksil yang berada pada dinding sel merupakan gugus ligan yang berkoordinasi dalam atom pusat logam melalui pasangan elektron bebas [3].
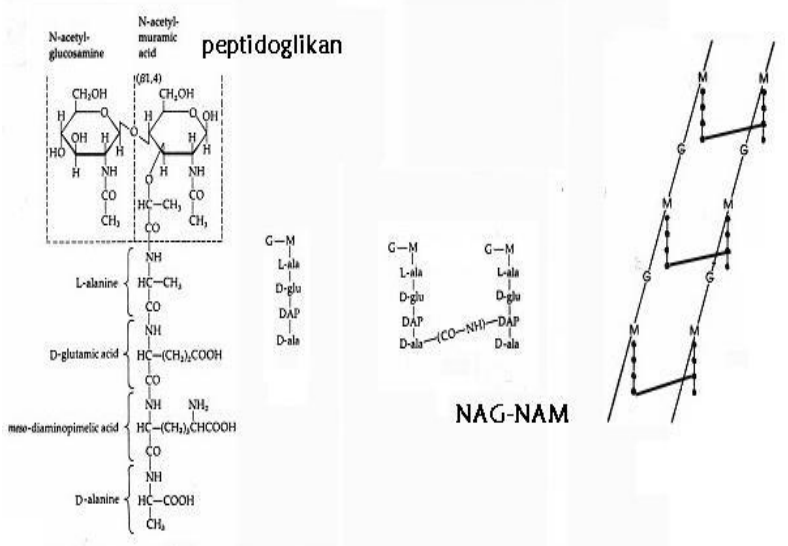

Gambar 4. Struktur Peptidoglikan pada Dinding Sel Bakteri

Dinding sel pada bakteri gram (+) juga memiliki polisakarida yang disebut asam teikoat. Asam teikoat yang merupakan polimer gliserol dan ribitol fosfat menempel pada peptidoglikan atau membran sitoplasma. Salah satu fungsi asam teikoat yang bermuatan negatif adalah untuk transport ion positif dari dan keluar sel.

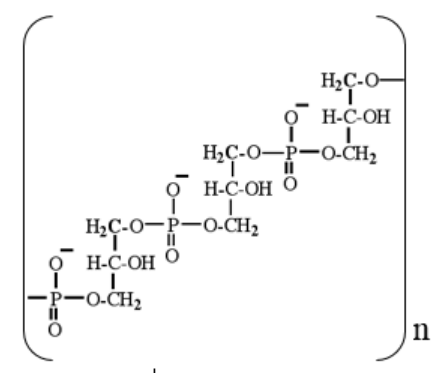

Gambar 5. Struktur Asam Teikoat

Mekanisme intraseluler secara simultan terjadi sejalan dengan konsumsi ion logam untuk pertumbuhan mikroorganisme atau akumulasi intraselular ion logam tersebut [3].

Hasil penelitian menunjukkan bahwa kedelapan isolat Geobacillus sp. mempunyai potensi untuk bioremediasi Fe(III). Pengurangan konsentrasi Fe(III) yang besar menunjukkan bahwa delapan isolat Geobacillus sp. cukup efektif untuk proses bioremediasi Fe(III). Dari kedelapan isolat Geobacillus sp., isolat dGae3 mampu mengabsorpsi Fe(III) paling tinggi, hal ini terbukti dari konsentrasi Fe (III) yang terakumulasi pada isolat dGae-3 paling tinggi, yaitu 99,85\%, sehingga dGae-3 paling efektif digunakan untuk bioremediasi $\mathrm{Fe}(\mathrm{III})$.

\section{Uji Potensi Bioremediasi $\mathrm{Pb}$ (II)}

Penelitian Hussein, $d k k$. [11] pada empat spesies Pseudomonas sp. menghasilkan bahwa keempat bakteri dapat mengakumulasi beberapa logam berbeda. Oleh karena itu, terdapat kemungkinan kedelapan isolat Geobacillus sp. mempunyai potensi bioremediasi untuk logam selain Fe.

Pellet bakteri Geobacillus sp. yang didapatkan diinokulasikan pada media BSM yang mengandung $\mathrm{Pb}$ (II) 7,5 ppm. Media yang telah ditanami bakteri tersebut diinkubasi selama 4 hari, hingga media terlihat keruh, yang menandakan bahwa bakteri telah tumbuh pada media BSM tersebut. Kultur Geobacillus sp. disentrifuge pada $4000 \mathrm{rpm}$ selama 10 menit untuk mengendapkan bakteri yang telah tumbuh. Filtrat yang didapatkan selanjutnya diuji kadar $\mathrm{Pb}$ (II) yang masih tersisa pada media dengan AAS dengan Panjang Gelombang 283,3 nm. Konsentrasi $\mathrm{Pb}(\mathrm{II})$ yang terakumulasi pada masing-masing isolat Geobacillus sp. dapat dilihat pada gambar 6 .

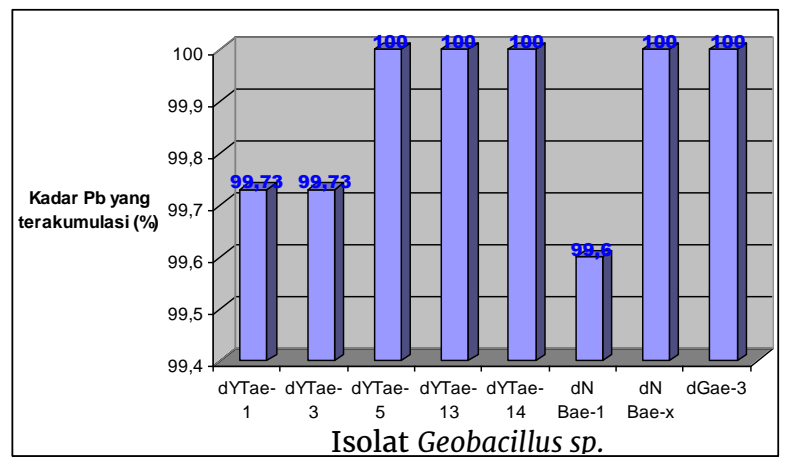

Gambar 6. Konsentrasi $\mathrm{Pb}$ (II) yang terakumulasi pada masing-masing isolat Geobacillus sp.

Berdasarkan data yang dihasilkan pada grafik, diketahui bahwa kadar $\mathrm{Pb}(\mathrm{II})$ pada media telah berkurang untuk masing-masing isolat Geobacillus sp. Bakteri Geobacillus sp. dapat beradaptasi dengan media yang mengandung $\mathrm{Pb}$ (II) yang merupakan logam berat. Dalam metabolismenya, logam berat $\mathrm{Pb}$ terakumulasi dalam membran sel (ekstraseluler) dan pada sitoplasma (intraseluler).

Akumulasi ekstraseluler $\mathrm{Pb}(\mathrm{II})$ terjadi dengan mekanisme yang sama dengan ion Fe(III) yaitu dengan adanya pengikatan ion-ion logam oleh polimer 
ekstraseluler yang dihasilkan sel-sel mikroba dan komplekasi antara ion-ion logam bermuatan positif dengan sisi reaktif permukaan sel yang bermuatan negatif.

\section{Uji Bioremediasi Hidrogen Peroksida $\left(\mathrm{H}_{2} \mathrm{O}_{2}\right)$}

Uji ini dilakukan dengan cara membuat stater dari delapan isolat Geobacillus sp. Gedong Songo yang telah diremajakan. Stater yang berumur 48 jam diambil dengan menggunakan mikro pipet kemudian diteteskan pada kaca preparat, dan ditetesi $\mathrm{H}_{2} \mathrm{O}_{2}$.

Adanya bioremediasi $\mathrm{H}_{2} \mathrm{O}_{2}$ pada mikroba dapat diketahui dengan terbentuknya gelembung-gelembung gas $\mathrm{O}_{2}$. Hidrogen peroksida $\left(\mathrm{H}_{2} \mathrm{O}_{2}\right)$ dapat terdekomposisi oleh enzim katalase yang dapat dihasilkan suatu mikroorganisme.

$2 \mathrm{H}_{2} \mathrm{O}_{2} \rightarrow 2 \mathrm{H}_{2} \mathrm{O}+\mathrm{O}_{2}$

Pada mikroorganisme, katalase tersebut berfungsi untuk melindungi sel dari efek toksik hydrogen peroksida [15]. Kontrol positif yang digunakan adalah S.aureus yang merupakan katalase positif. S.aureus diteteskan pada kaca preparat dan ditambah setetes $\mathrm{H}_{2} \mathrm{O}_{2}$. Gelembung-gelembung gas $\mathrm{O}_{2}$ pada sel S.aureus tersebut timbul setelah 5 detik.

Hasil penelitian tidak menunjukkan adanya gelembung-gelembung gas pada masing-masing isolat Geobacillus sp. yang ditetesi $\mathrm{H}_{2} \mathrm{O}_{2}$ dimana mengindikasikan bahwa $\mathrm{H}_{2} \mathrm{O}_{2}$ yang ditambahkan tidak terurai menjadi gas $\mathrm{O}_{2}$ oleh Geobacillus sp.

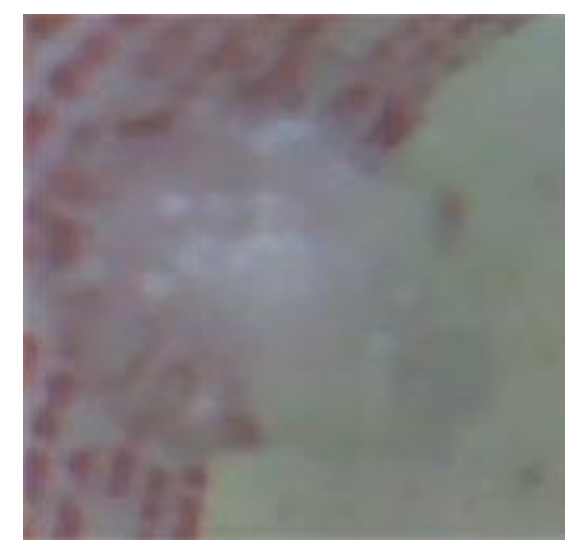

Kontrol

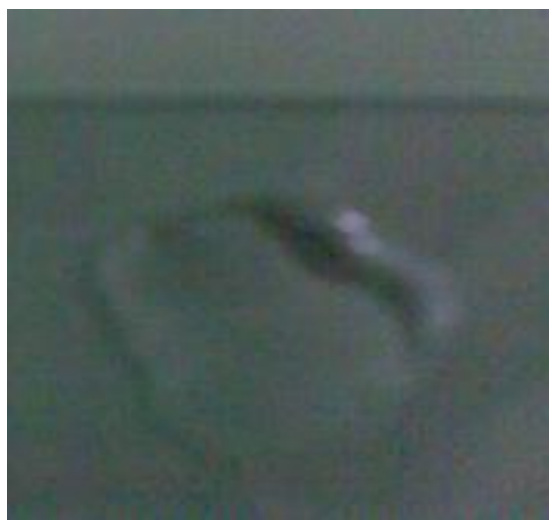

hasil uji

Gambar 7. Uji gelembung gas pada masing-masing isolat Geobacillus $s p$
Sebagian besar bakteri dari genus Geobacillus dapat menghasilkan enzim katalase [16]. Pada penelitian ini, kedelapan isolat Geobacillus sp. tidak dapat menghasilkan katalase, kemungkinan disebabkan sifat bakteri yaitu mikroaerofil dimana isolat Geobacillus sp. hanya membutuhkan sedikit $\mathrm{O}_{2}$ untuk pertumbuhannya [9]. Sehingga jika $\mathrm{H}_{2} \mathrm{O}_{2}$ terurai menjadi $\mathrm{O}_{2}$, maka $\mathrm{O}_{2}$ yang terbentuk tersebut malah akan menjadi racun bagi isolat Geobacillus sp. Katalase adalah suatu enzim yang dihasilkan oleh sebagian besar mikroorganisme aerofil yang membutuhkan $\mathrm{O}_{2}$ untuk pertumbuhannya [15], namun pada penelitian ini, isolat dYTae-14 yang bersifat aerofil juga tidak dapat menghasilkan katalase. Dalam suatu lingkungan tertentu, organisme yang tidak memproduksi katalase (katalase negatif) dilindungi oleh organisme lain yang mempunyai kemampuan memproduksi enzim katalase (katalse positif). Bakteri katalase positif mendekomposisi $\mathrm{H}_{2} \mathrm{O}_{2}$ dalam lingkunan tersebut, sehingga bakteri katalase negatif terlindung dari efek toksik $\mathrm{H}_{2} \mathrm{O}_{2}$ [15].

Berdasarkan hasil penelitian tersebut, dapat disimpulkan bahwa kedelapan isolat Geobacillus sp. adalah termasuk bakteri katalase negatif yaitu bakteri yang tidak dapat menghasilkan enzim katalase sehingga tidak dapat digunakan untuk bioremediasi $\mathrm{H}_{2} \mathrm{O}_{2}$.

\section{Uji Kualitatif Enzim Amilase Ekstraseluler}

Uji ini dilakukan dengan cara membuat media BSM padat yang mengandung $1 \%$ pati kanji dan menumbuhkan isolat bakteri Geobacillus sp. pada media tersebut. Pati kanji yang ditambahkan pada media padat tersebut berperan sebagai substrat yang dapat diuraikan oleh enzim amylase [17].

Setelah inkubasi 48 jam, bagian media padat yang ditanami 8 isolat Geobacillus sp.terlihat keruh. Hal ini menunjukkan bahwa 8 isolat Geobacillus sp. telah tumbuh pada masing-masing media padat yang mengandung $1 \%$ pati kanji. Untuk membuktikan apakah 8 isolat Geobacillus sp. menghasilkan enzim amilase ekstraseluler, maka kultur Geobacillus sp. tersebut di tetesi iodin [18].

Hasil penelitian menunjukkan di sekeliling delapan isolat Geobacillus sp. terdapat zona bening. Hal ini menunjukkan bahwa amilum yang terdapat pada media di sekitar isolat Geobacillus sp. telah terhidrolisis menjadi monosakaridanya, yaitu glukosa [19]. 


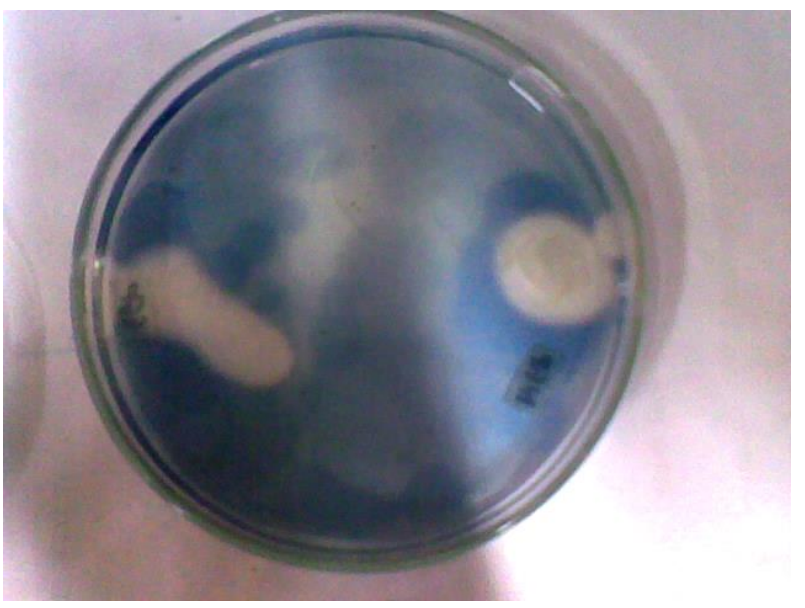

Gambar 8. Uji enzim amilase ekstraseluler

Hasil ini membuktikan bahwa kedelapan isolat Geobacillus sp. dapat menghasilkan enzim amilase yang disekresikan ke dalam medium sehingga amilum (pati) yang terdapat pada medium dapat terurai. Enzim amilase, meliputi $\alpha$-amilase, $\beta$-amilase dan glukoamilase [20]. Enzim $\alpha$-amilase (E.C. 3.2.1.1) bekerja menghidrolisis ikatan $\alpha-1,4$ secara acak di bagian dalam molekul antar unit glukosa di dalam rantai amilosa yang linier. Hasil hidrolisis $\alpha$-amilase mula-mula akan menghasilkan dekstrin, dekstrin tersebut kemudian dipotong-potong lagi menjadi campuran antara glukosa dan maltosa [21]. Enzim $\beta$-amilase memotong pada ikatan $\alpha-1,4$ pada unit maltosa dari rantai amilum yang belum terputus sempurna. Enzim glukoamilase (E.C. 3.2.1.3) atau sering disebut amiloglukosidase atau $\alpha-$ 1,4-glukano glukohidrolase merupakan enzim ekstraseluler yang mampu menghidrolisis ikatan $\alpha-1,4$ pada rantai amilosa dan amilopektin. Enzim glukoamilase juga dapat menyerang ikatan $\alpha-1,6$ pada titik percabangan, walaupun dengan laju yang lebih rendah. Hal ini berarti bahwa pati dapat diuraikan secara sempurna menjadi glukosa [22].

\section{Uji Kualitatif Enzim $\beta$-Galaktosidase Ekstraseluler}

Uji ini dilakukan dengan cara menumbuhkan delapan isolat Geobacillus sp. dalam media BSM cair yang mengandung $1 \%$ laktosa. Laktosa yang ditambahkan tersebut berfungsi sebagai induser [8]. Keberadaan dari enzim $\beta$-Galaktosidase dapat diketahui dengan menggunakan ONPG (o-nitrovenil- $\beta$-D-Galaktosidase) sebagai substrat. Substrat ONPG ditambahkan pada kultur Geobacillus sp. [23].

Uji positif adanya aktivitas enzim $\beta$-Galaktosidase pada media Geobacillus sp. ditunjukkan oleh terjadinya perubahan warna pada media menjadi kuning terang. Hal ini disebabkan ONPG dihidrolisis oleh enzim $\beta-$ Galaktosidase menjadi ONP (o-nitrofenol) dan galaktosa. ONPG merupakan senyawa tak berwarna, tetapi hasil hidrolisisnya yaitu ONP (o-nitrofenol) adalah senyawa yang berwarna kuning [8].

Hasil uji kualitatif enzim $\beta$-Galaktosidase ekstraseluler yang telah dilakukan menunjukkan tidak ada perubahan warna pada kedelapan media BSM. Hal ini disebabkan tidak adanya produk ONP (o-nitrofenol) hasil reaksi enzimatis dan membuktikan bahwa kedelapan isolat Geobacillus sp. tidak memiliki enzim $\beta-$ Galaktosidase ekstraseluler.

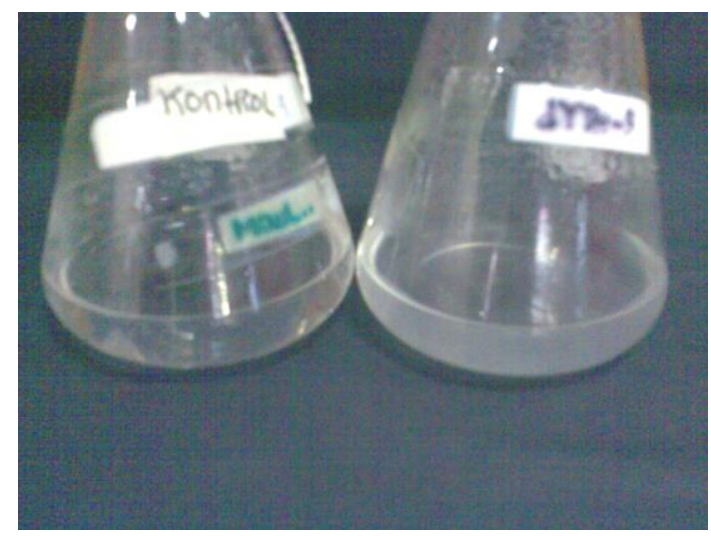

Gambar 9. Uji Enzim $\beta$-Galaktosidase Ekstraseluler

\section{Uji Kualitatif Enzim Protease Ekstraseluler}

Uji ini dilakukan dengan cara menumbuhkan delapan isolat Geobacillus sp. pada media BSM cair yang mengandung gelatin. Setelah inkubasi 24 jam media menjadi sedikit keruh. Hal ini disebabkan isolat Geobacillus sp. telah tumbuh pada media tersebut. Setelah itu masing-masing media disimpan di dalam lemari es selama 15 menit [24].

Pada penelitian ini, kedelapan media menunjukkan hasil positif. Hal ini dibuktikan dari masing-masing media BSM-gelatin tetap cair setelah pendinginan. Media BSM-gelatin yang tidak ditumbuhi isolat Geobacillus sp. menjadi beku. Gelatin merupakan protein yang diperoleh dari hidrolisis kolagen yang secara alami terdapat pada tulang atau kulit binatang. Gelatin meleleh bila dipanaskan, namun akan segera menjadi padat lagi apabila didinginkan. Bila bercampur dengan air, gelatin akan membentuk larutan dengan viskositas tinggi yang juga akan menjadi padat (gel) bila mendingin [25].

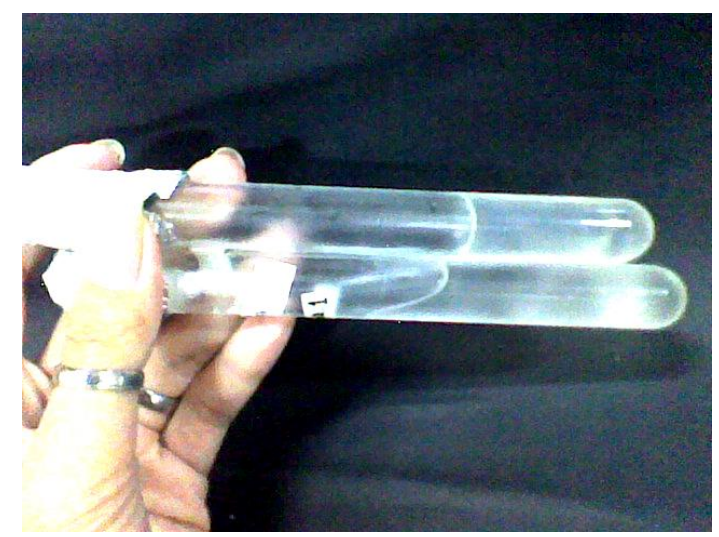

Gambar 9. Uji Kualitatif Enzim Protease Ekstraseluler

Dari hasil penelitian ini, dapat diketahui bahwa gelatin pada media BSM telah terhidrolisis menjadi asam amino penyusunnya, yaitu asam amino non esensial contohnya glisin dan prolin [25]. Oleh sebab itu media yang telah ditumbuhi isolat Geobacillus sp. tidak membeku setelah pendinginan. Hal ini membuktikan 
bahwa telah terjadi aktivitas protease yang dihasilkan oleh kedelapan isolat Geobacillus sp. pada media tersebut.

Hasil penelitian ini menunjukkan adanya kesamaan potensi enzim protease ekstraseluler dengan bakteri yang diisolasi oleh Susilawati [24]. Dalam penelitiannya, Susilawati telah berhasil mengisolasi bakteri penghasil enzim protease termostabil dari sumber air panas Gedong Songo. Bakteri tersebut berbentuk batang dan termasuk bakteri gram positif, dimana sifat tersebut sama dengan kedelapan isolat Geobacillus sp. Adanya kesamaan sifat dan potensi dari bakteri-bakteri tersebut menunjukkan adanya kemungkinan bahwa bakteri yang ditemukan Susilawati tersebut merupakan salah satu isolat Geobacillus sp. atau memiliki kekerabatan yang dekat dengan Geobacillus sp.

\section{Kesimpulan}

Dari pohon filogeni diketahui bahwa kedelapan isolate Geobasillus sp. berada dalam tingkat kekerabatan yang dekat dan memiliki hubungan kekerabatan terdekat dengan Geobacillus sp._TERI_NSM dan Geobacillus sp. sbs3. Kedelapan isolat Geobasillus sp. mempunyai potensi bioremediasi terhadap Fe(III) dan $\mathrm{Pb}(\mathrm{II})$ akan tetapi tidak mempunyai potensi bioremediasi $\mathrm{H}_{2} \mathrm{O}_{2}$. Hasil uji enzim termostabil ekstraseluler menunjukkan bahwa kedelapan isolat Geobasillus sp. memiliki amilase dan protease termostabil ekstraseluler namun tidak memiliki $\beta$ Galaktosidase termostabil ektraseluler.

\section{Daftar Pustaka}

[1] W Deden Trismillah, Produksi Xilanase Sumaryanto, Pengaruh Komposisi Media pada Produksi Xilan, Bacillus stearothermophillus DSM 22 Menggunakan Substrat Kulit Buah Pisang, Pustaka IPTEK J, Sains dan Teknologi BPPT, VII. IIA, 1 (2005).

[2] Wakao Fukuda, Yulia Sari Ismail, Toshiaki Fukui, Haruyuki Atomi, Tadayuki Imanaka, Characterization of an archaeal malic enzyme from the hyperthermophilic archaeon Thermococcus kodakaraensis KOD1, Archaea, 1 (2005) 293-301.

[3] Suhendrayatna, Bioremoval Logam Berat Dengan Menggunakan Microorganisme: Suatu Kajian Kepustakaan (Heavy Metal Bioremoval by Microorganisms: A Literature Study ), in: Seminar On-Air, Bioteknologi untuk Indonesia Abad 21, Sinergy Forum - PPI Tokyo Institute of Technology, Japan, 2001.

[4] Tuty Alawiyah, Kultivasi Anaerob dan Identifikasi Fragmen 396 pb (550-945) Gen 16S rRNA Bakteri Geobacillus thermoleovorans T4 Isolat Sumber Air Panas Gedong Songo, in, Jurusan Kimia Universitas Diponegoro, Semarang, 2007.

[5] M. S. Friedman, Thermophilic Microorganism, Academic Press, Inc. New York 1992.

[6] J Van Lieshout, M Faijes, J Nieto, J Van Der Oost, A Planas, Hydrolase and glycosynthase activity of endo-1, 3- $\beta$-glucanase from the thermophile Pyrococcus furiosus, Archaea, 1 (2004) 285-292.
[7] S. Marvin Friedman, Protein Synthesis in Cell-Free Extracts from a Thermoacidophilic Archaebacterium, Systematic and Applied Microbiology, 6 (1985) 1-6.

[8] Sophie Drouault, Jamila Anba, Gérard Corthier, Streptococcus thermophilus is able to produce a $\beta$ galactosidase active during its transit in the digestive tract of germ-free mice, Applied and environmental microbiology, 68 (2002) 938-941.

[9] Agustina L. N. Aminin, F. Madayanti, P. Aditiawati, Akhmaloka, Isolation of Thermophiles From Gedongsongo Hot Spring Using A Simple Enrichment Medium, in: International Seminar Advance in Biological Science, 2007.

[10] Djedi S Widarto, Tedi Yudistira, Karakterisasi Sumberdaya Panas Bumi Skala Kecil di Zona Depresi Volkanik Ungaran Jawa Tengah, (2004).

[11] Hany Hussein, Soha Farag Ibrahim, Kamal Kandeel, Hassan Moawad, Biosorption of heavy metals from waste water using Pseudomonas sp, Electronic Journal of Biotechnology, 7 (2004) 30-37.

[12] E Stackebrandt, BM Goebel, Taxonomic note: a place for DNA-DNA reassociation and 16S rRNA sequence analysis in the present species definition in bacteriology, International Journal of Systematic and Evolutionary Microbiology, 44 (1994) 846-849.

[13] Adrian Nur, Immobilisasi Limbah Fermentasi Pabrik Alkohol Terhadap Adsorpsi Logam Berat Kadmium (Cd), Ekuilibrium, 6 (2007) 27-31.

[14] Ventsislava Yankova Petrova, Tanya Vassileva Rasheva, Anna V Kujumdzieva, Catalase enzyme in mitochondria of Saccharomyces cerevisiae, Electronic Journal of Biotechnology, 5 (2002) 11-12.

[15] L Luhova, A Lebeda, D Hedererová, P Pec, Activities of amine oxidase, peroxidase and catalase in seedlings of Pisum sativum L. under different light conditions, Plant soil and environment, 49 (2003) 151-157.

[16] DR Zeigler, Bacillus Genetic Stock Center Catalog of Strains, vol. 3, The Genus Geobacillus, in, 2001.

[17] R Borris, Biological Role of Enzymes, eds. Biotechnology ed., UCH, Germany, 1987.

[18] Elidar Naiola, Mikrobia Amilolitik pada Nira dan Laru dari Pulau Timor, Nusa Tenggara Timur, Biodiversitas, 9 (2008).

[19] R. Melliawati, R.S. Suherman, B. Subardjo, Pengkajian Kapang Endofit dari Taman Nasional Gunung Halimun sebagai Penghasil Glukoamilase, Pusat Penelitian Bioteknolgi LIPI, 2006.

[20]LM Josson, LM Coronel, BB Mercado, ED De Leon, OG Mesina, AM Lozano, MB Bigol, Strain improvement of aspergillus oryzae for glucoamylase production, Asean Journal on Science and Technology for Development, 9 (1992) 1-116.

[21] R Melliawati, E Sukara, Pengaruh sumber pati dan nitrogen terhadap produksi enzim amilolitik oleh khamir Saccharomycopsis sp. TJ-1, in: Simposium Nasional Bioteknologi - Dies Natalis ke-37 UNAIR, Universitas Airlangga, Surabaya, 1991.

[22]John M Deman, Kimia makanan, Penerbit ITB. Bandung, (1997). 
[23]Joseph Sambrook, David W Russell, Molecular cloning: a laboratory manual 3rd edition, Coldspring-Harbour Laboratory Press, UK, (2001).

[24]Tuti Susilawati, Isolasi dan karakterisasi enzim protease dari isolat bakteri termofilik sumber air panas Gedong Songo Bawen, in, FMIPA UNDIP, 2004.

[25]Alan Gordon Ward, Albert Courts, Science and technology of gelatin, Academic Press, 1977. 